\title{
Feeding pattern of an Indian major carp, Labeo rohita (Hamilton, 1822) in periphyton based monoculture and polyculture earthen pond
}

\author{
Sandip Majumder ${ }^{1}$, Neha Majumdar ${ }^{2}$, Pinki Ghosh ${ }^{3 *}$, Kousik Roy ${ }^{4}$, \\ Surjya Kumar Saikia ${ }^{1}$, Samar Kumar Saha ${ }^{2}$
}

${ }^{1}$ Fish Biology and Aquatic Ecology Laboratory, Department of Zoology, Visva-Bharati University, Santiniketan, West Bengal, India, Pin-731235

${ }^{2}$ Fish Biology Research Unit, Department of Zoology, Visva-Bharati University, Santiniketan, West Bengal, India, Pin-731235

${ }^{3}$ Fisheries Laboratory, Department of Zoology, Visva-Bharati University, Santiniketan, West Bengal, India, Pin-731235

${ }^{4}$ Fish Biology and Toxicology Laboratory, Department of Zoology, Visva-Bharati University, Santiniketan, West Bengal, India, Pin-731235

*Corresponding author e-mail: pinkighosh0504@gmail.com

Available online at: www.isroset.org

Accepted: 17/Aug/2018, Online: 30/Aug/ 2018

\begin{abstract}
Food selection of Labeo rohita were studied in periphyton based monoculture and polyculture environment. Electivity Index was used to determine the diet selection under two different culture environments. The fish fed a range of diet. Feed study revealed that fingerlings and adults of rohu differ significantly in selection of food items. More particularly algal groups were taken predominantly during all the growth stages, however, the fish strongly rejected most of the large zooplankton and zooperiphyton during the later months. This investigation found that rohu feed on phytoplankton throughout the life even in the early stage of life. But at early stage it prefers to consume zooplankton in higher quantity and phytoplankton in less quantity, even some blue green algae is preferred throughout the ontogeny of the fish. The study revealed planktivorous nature of feeding of rohu mostly on algal food organisms from both periphytic and planktonic origin and suggests that rohu extends its feeding niche to periphyton along with plankton in substrate based system.
\end{abstract}

Keywords- Periphyton, Plankton, Polyculture, Labeo rohita, Gut content, Electivity index

\section{INTRODUCTION}

Utilization pattern of natural aquatic food resources is an important area of research to get better production of fish form aquaculture farming. Labeo rohita (rohu) is an important freshwater fish species normally cultured in Asia particularly in the Indian subcontinent. The fish is a natural inhabitant of the riverine system of northern and central India. Its high growth potential, coupled with high consumer preference, have established rohu as the most important freshwater species cultured in India, Bangladesh and other adjacent countries in the region. Its compatibility for resource utilization with other freshwater carps, mainly catla (Catla catla) and mrigal (Cirrhinus mrigala) made it an ideal candidate for polyculture [1]. Despite enormous potentiality in polyculture, the food and feeding ecology of rohu has not been studied extensively.

Rohu contributes to $15 \%$ of world's freshwater aquaculture production [2]. It has scanty information on feeding strategies on natural organisms. It feeds on plankton from water column $[3,4,5]$. On the basis of gut content analysis, it was reported as zooplankton feeder [6] or both zoo and phytoplankton feeder [5] or periphyton feeder [7, 8, 9]. Muhammad et al. (2006) [10] found differential size dependent diet composition and divergent dietary preference between $L$. rohita and Cyprinus carpio in semi intensive ponds. Khan and Siddique (1973) [11] also studied food selection and feeding relationship of L. rohita with $C$. catla and $C$. mrigala and concluded $L$. rohita as zooplankton feeder in fingerling and phytoplankton feeder in adult stage. There are a few researches so far done on food selection of this fish in periphytic system. Based on these backgrounds the present study aimed to investigate the actual feeding strategy of rohu in periphytic system under mono and polyculture condition.

\section{MATERIALS AND METHODS}

\section{Experimental set up}

The study was performed in a conventional fish pond for a period of seven months in rural Bolpur of Birbhum district, West Bengal, India. The pond was divided into two halves with the help of fine nylon net that were fixed in bamboo poles. For colonization and growth of 
periphytic organisms, bamboo poles (lengths $2.7 \pm 0.23 \mathrm{~m} \&$ diameters $5.5 \pm 0.38 \mathrm{~cm}$ ) that acted as natural substrates, were implanted in the pond at a distance of 1 meter from each other $\left(4\right.$ poles $\left./ \mathrm{m}^{2}\right)$ in both the halves of the pond before one month of introduction of fish into the pond so that periphytic organisms will get enough time to colonize on the bamboo poles. Fishes were released in both experimental plots. In one half of the pond, Labeo rohita at fingerling stage (average weight $8.58 \pm 1.21 \mathrm{~g}$, average total length $7.5 \pm$ $0.82 \mathrm{~cm}$ ) were released 15 days prior to first sampling and this area was considered as periphytic monoculture (PRM) system. In the second half of the pond, along with rohu, Catla catla (average wt. $8.81 \pm 1.78 \mathrm{~g}$, average length $7.1 \pm$ $0.71 \mathrm{~cm}$ ) and Cirrhinus mrigala (average wt. $4.52 \pm 0.74 \mathrm{~g}$, average length $5.3 \pm 0.56 \mathrm{~cm}$ ) were also introduced and this area considered as the periphytic polyculture (PR-P) system.

\section{Fish sampling and gut collection}

A total of 20 fishes from each experimental area during every sampling were collected in 30 days intervals. Total six samplings were done during the whole study period starting from the month of June up to November. All fish were collected before 9:00 AM from the experimental pond with the help of fish net. Before gut collection, every fish was weighed and total length was recorded. The guts were cut from pharynx region to first constriction of alimentary canal. This length is around 4.5-12.6 cm proportionately to the total body length of the fish. Immediately after collection, guts were transferred to $10 \%$ formalin. In laboratory, gut contents were removed with scalpel visible up to naked eyes. These were then preserved in $4 \%$ formalin in $5 \mathrm{ml}$ glass vials for further analysis.

\section{Resource sampling}

Two resources i.e. plankton and periphyton from both the periphytic monoculture and polyculture were considered. Samplings of all resources were done at the same time of gut collection. Plankton samples were collected randomly from the different area of the pond with plankton net $(0.20 \mu \mathrm{m}$ mesh size $)$ filtering approximately 30 Liter water every time and transferred to a $15 \mathrm{ml}$ glass vial. Periphyton samples were randomly scrapped from an area of $10 \mathrm{~cm}^{2}$ from the surfaces of the bamboo poles, then mixed and stored in a $15 \mathrm{ml}$ glass vial. All samples of plankton and periphyton were then preserved in $4 \%$ formalin for further analysis.

\section{Identification and Quantification of samples}

Calculations of gut contents and resource samples were done following Lackey's (1938) [12] drop count methods under an inverted microscope (Victory plus, Dewinter, Italy) in 400x magnification. Organisms were identified up to generic level and wherever possible identified up to species level using standard manuals [13, $14,15]$. In case of gut content of fish, the whole gut contents collected from each gut were analyzed.

\section{Food Selectivity Study}

Ivlev's (1961) [16] electivity index was used to measure the selection of available food organisms by fish: $E_{i}$ $=\mathrm{St}_{\mathrm{i}}-\mathrm{P}_{\mathrm{i}} / \mathrm{St}_{\mathrm{i}}+\mathrm{P}_{\mathrm{i}}$ where $\mathrm{E}_{\mathrm{i}}=$ electivity index for species $\mathrm{I}, \mathrm{St}_{\mathrm{i}}$ $=$ relative proportion of species $\mathrm{i}$ in the diet, $\mathrm{P}_{\mathrm{i}}=$ relative proportion of species $i$ in the environment. $E$ values vary from -1 to +1 , values around 0 indicate no selection, a value of +1.0 indicates strong positive selection, and -1.0 indicates strong avoidance.

\section{RESULTS}

\section{Planktonic and Periphytic organisms}

A total of 40 phytoplankton genera were identified from pond water during the study period. Chlorophyceae and Bacillariophyceae were dominant than groups. 12 genera of zooplankton were identified belonging to Crustacea, Rotifera, Cladocera and Copepoda. 37 genera of periphytic organism from the bamboo substrates were identified belonging to four major algal groups (Bacillariophyceae, Chlorophyceae, Cyanophyceae and Euglenophyceae) and 12 genera of zooplankton were also identified.

\section{Gut content organisms of rohu}

Gut contents study showed a wide variety of food organisms present in the diet of rohu at fingerling and adult stages. In both the culture system a total of 39 genera of phytoplankton belonging to Chlorophyceae, Bacillariophyceae, Cyanophyceae and Euglenophyceae and 12 genera of zooplankton belonging to Crustacea, Rotifera, Cladocera and Copepoda were recorded in the gut content of rohu. The fraction of these food items used by the fish showed great variation with the progress of the season.

\section{Feeding strategy}

At the beginning of the season i.e. in the month of June-July, in both periphytic monoculture (PR-M) and periphytic polyculture (PR-P) systems, rohu showed negative selection for most of the planktonic as well as periphytic algal genera (Fig-1, 2, 3 and 4). At this stage the fish showed positive selection for various zooplanktonic organisms. Among Rotifers Brachionus, Keratella and Filinia, among Cladocera Moina and Daphnia, among Copepoda Cyclops and Diaptomus were preferred over the other zooplankton. Although, Arcella the only zooplankton which was abundant in the gut throughout the months, but rohu showed negative selection for this organism during the later period of months. As the time progressed, the situation varied largely and from August onwards, the frequency of avoidance declined for algal groups and the electivity 
indices revealed wide range of selection indicating weak avoidance to strong selection for both planktonic and periphytic algal organisms. During this phase, in both the PR-M and PR-P systems, rohu gradually extended the resource limit towards the four major planktonic as well as periphytic algal groups, mostly preferring Chlorophyceae like Chlorella, Closterium, Scenedesmus, Oedogonium, Kirchneriella, Closteriopsis, Cosmarium, Ankistrodesmus, Characium, Stigeoclonium etc., followed by Bacillariophyceae like Navicula, Diatoma, Nitzschia, Cyclotella, Synedra, Pinnularia, Cymbella, Gomphonema etc., Cyanophyceae like Anabaena, Aphanocapsa, Chroococus, Gloeocapsa, etc and Euglenophyceae like Phacus, Euglena, Trachelomonus etc. However, during late period of months, rohu showed negative selection for almost all zooplanktonic organisms in both monoculture and polyculture (Fig-1, 2, 3 and 4). Rohu showed positively high selection for mostly the genera which are common in both the planktonic and periphytic resource like Chlorella, Closterium, Scenedesmus, Oedogonium from
Chlorophyceae, Navicula from Bacillariophyceae, Anabaena, Chroococus from Cyanophyceae and Phacus, Euglena from Euglenophyceae. In case of sole planktonic genera, Diatoma from Bacillariophyceae and Aphanocapsa from Cyanophyceae were highly preferred. Whereas the fish showed moderate preference to genera like Gloeocapsa, Coelastrum, Pediastrum, Spirogyra, Surirella etc. But in case of sole periphytic genera, rohu showed positive selection for Phormidium, Stigeoclonium and Amphora. The fish avoided certain predominantly available genera throughout the months although the abundance of some of the organisms were quite high in the pond environment like Merismopedia, Spirulina from planktonic genera and Hapalosiphon, Zygnema from periphytic genera. Volvox and Microcystis were also avoided throughout the season although they were common genera in both plankton and periphyton. However, the fish preferred some of the algal genera throughout the seasons, even when it preferred to consume zooplankton.
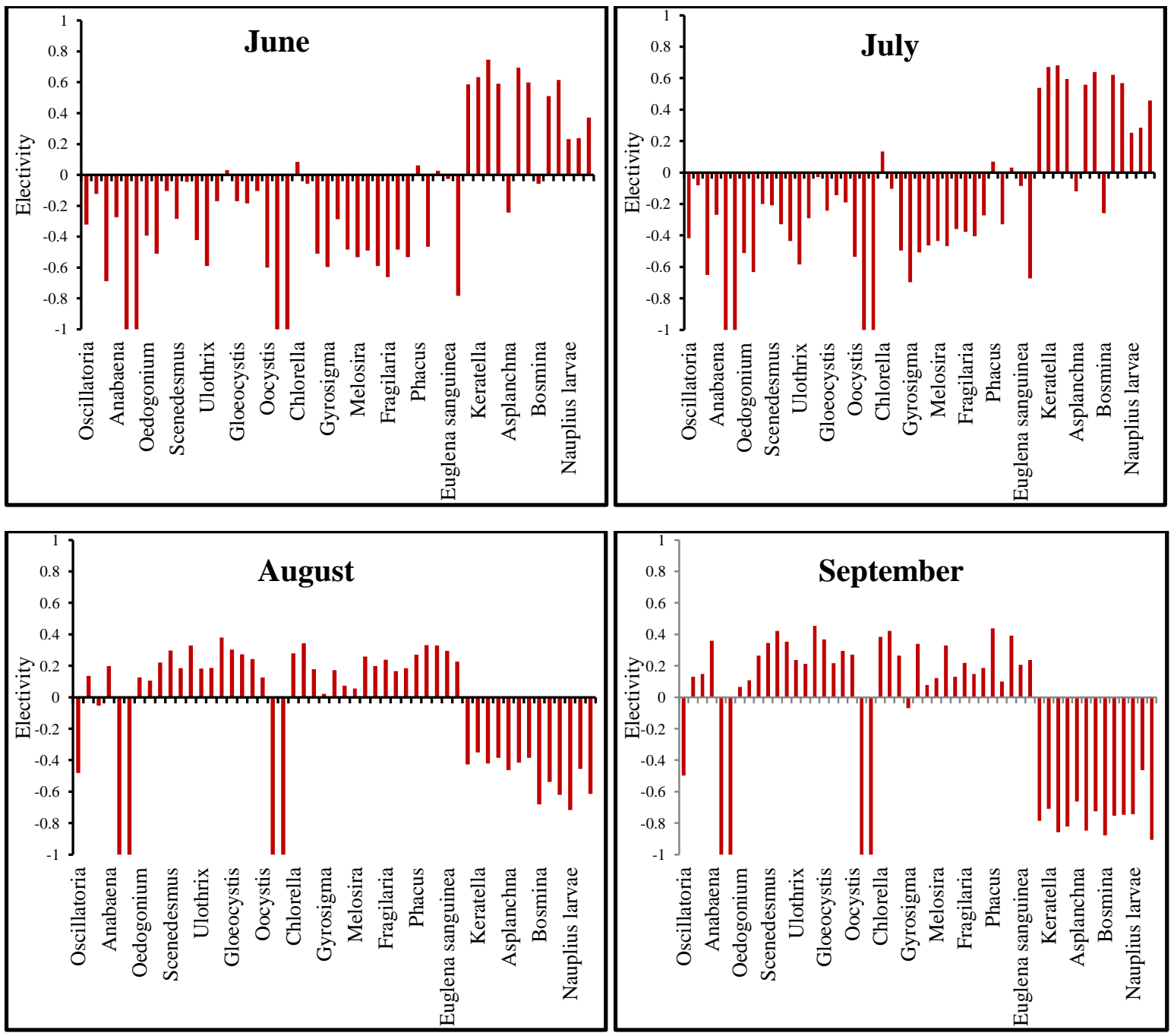

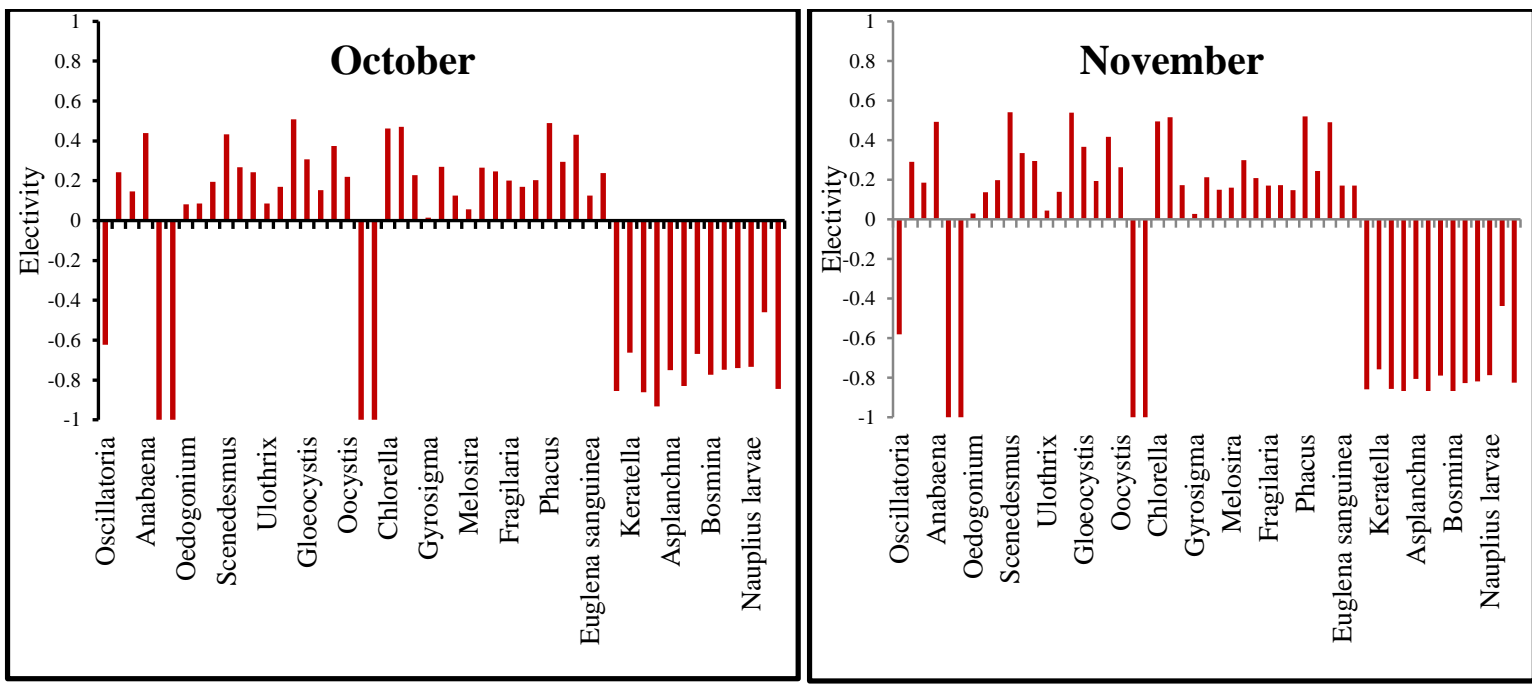

Fig-1: Ivlev's Electivity index throughout the season in Periphytic monoculture (PR-M) system considering periphyton as food resource.


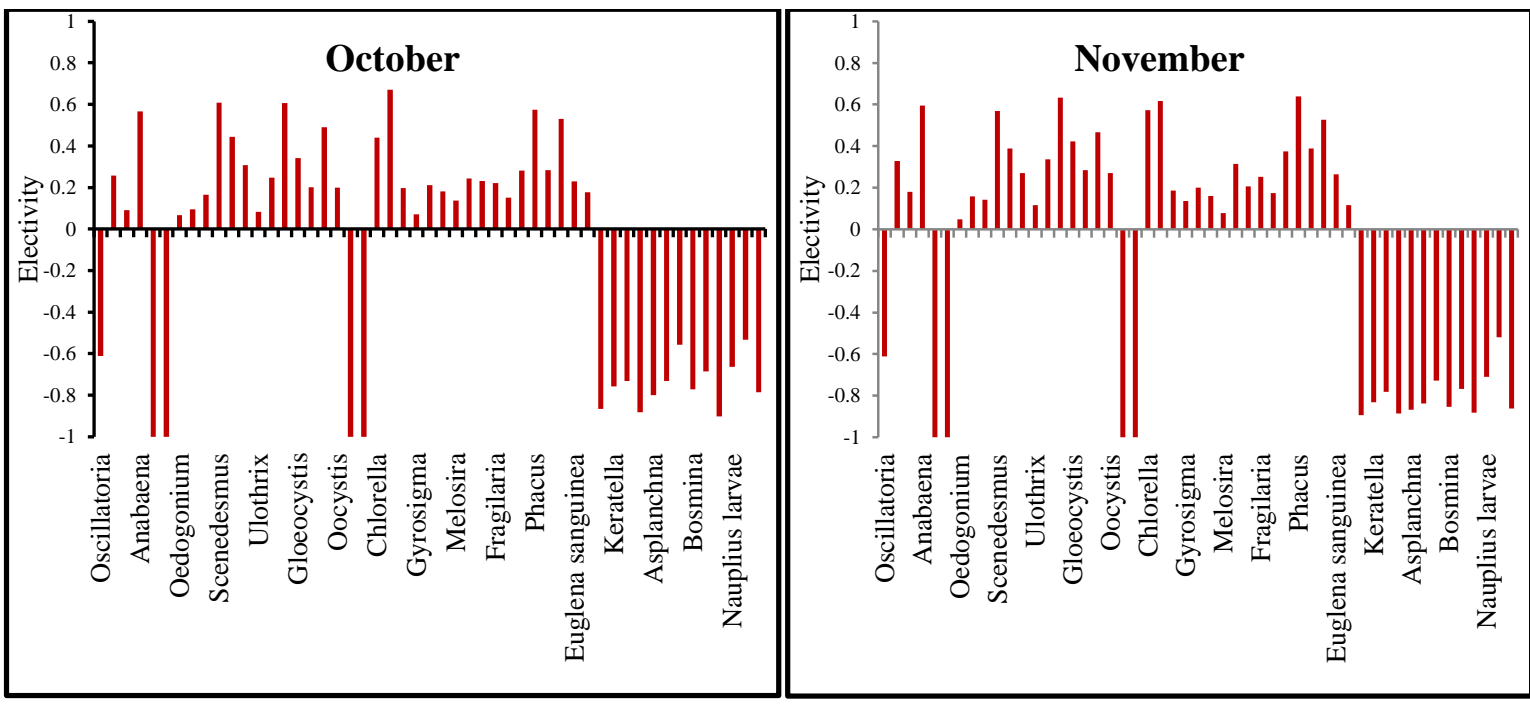

Fig-2: Ivlev's Electivity index throughout the season in Periphytic polyculture (PR-P) system considering periphyton as food resource.
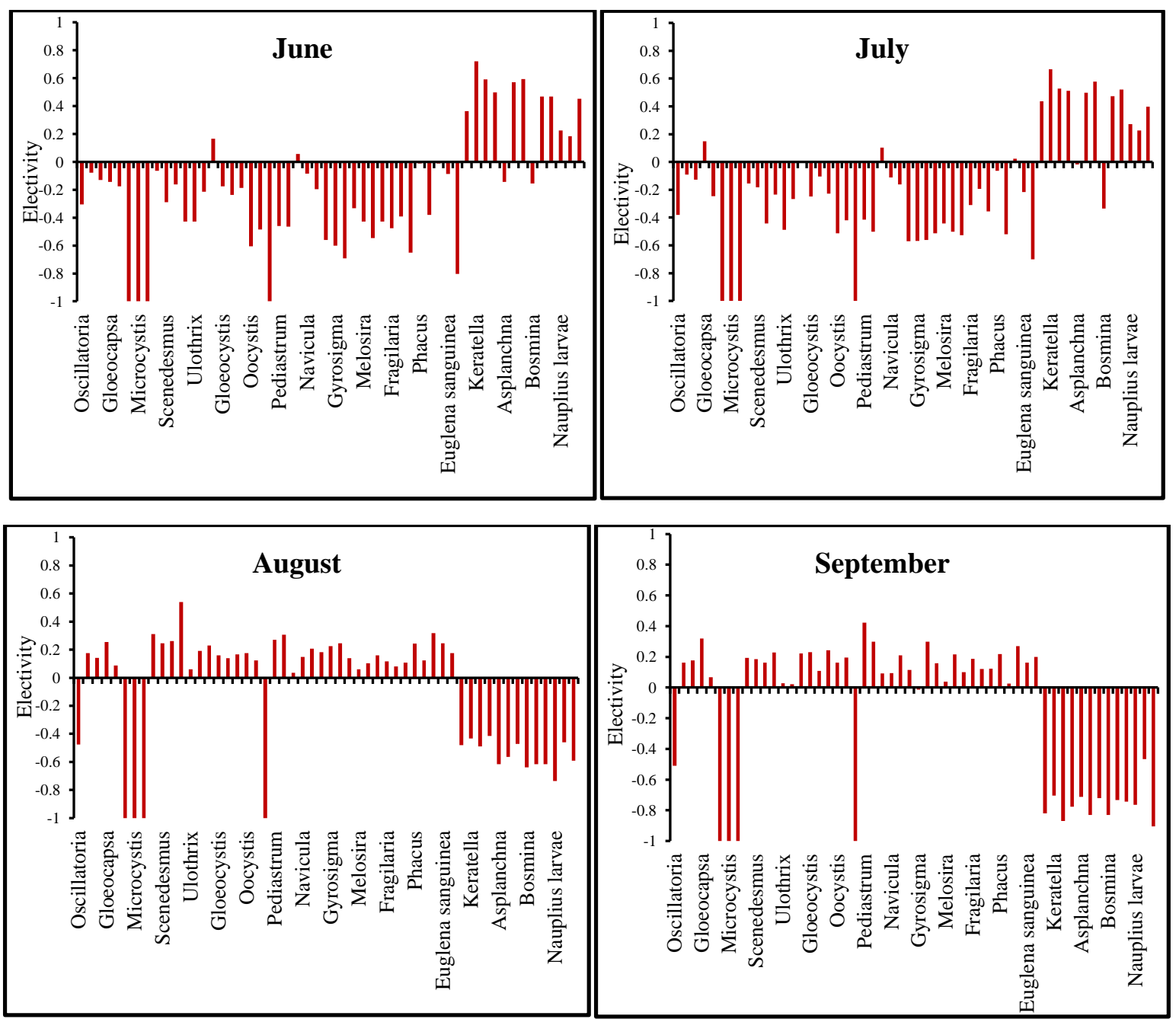


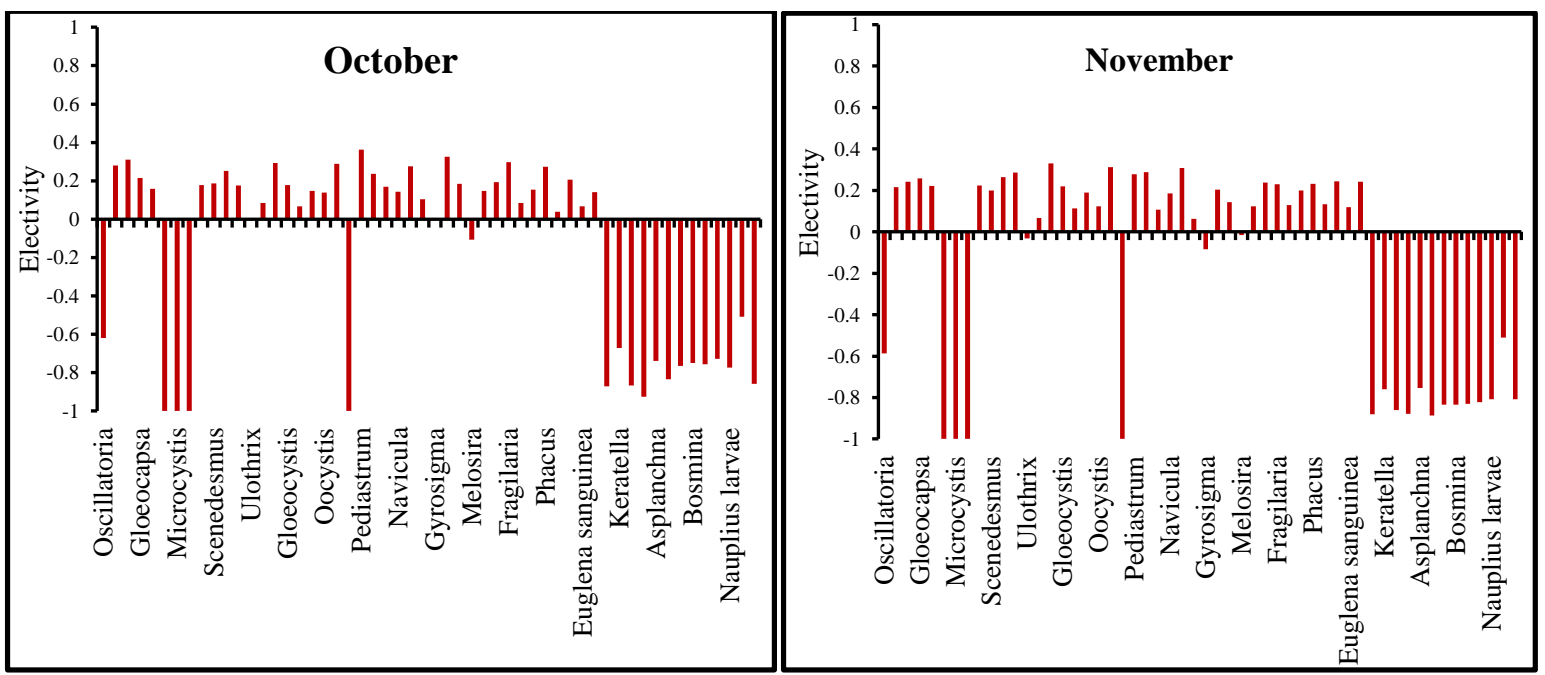

Fig-3: Ivlev's Electivity index throughout the season in Periphytic monoculture (PR-M) system considering plankton as food resource.
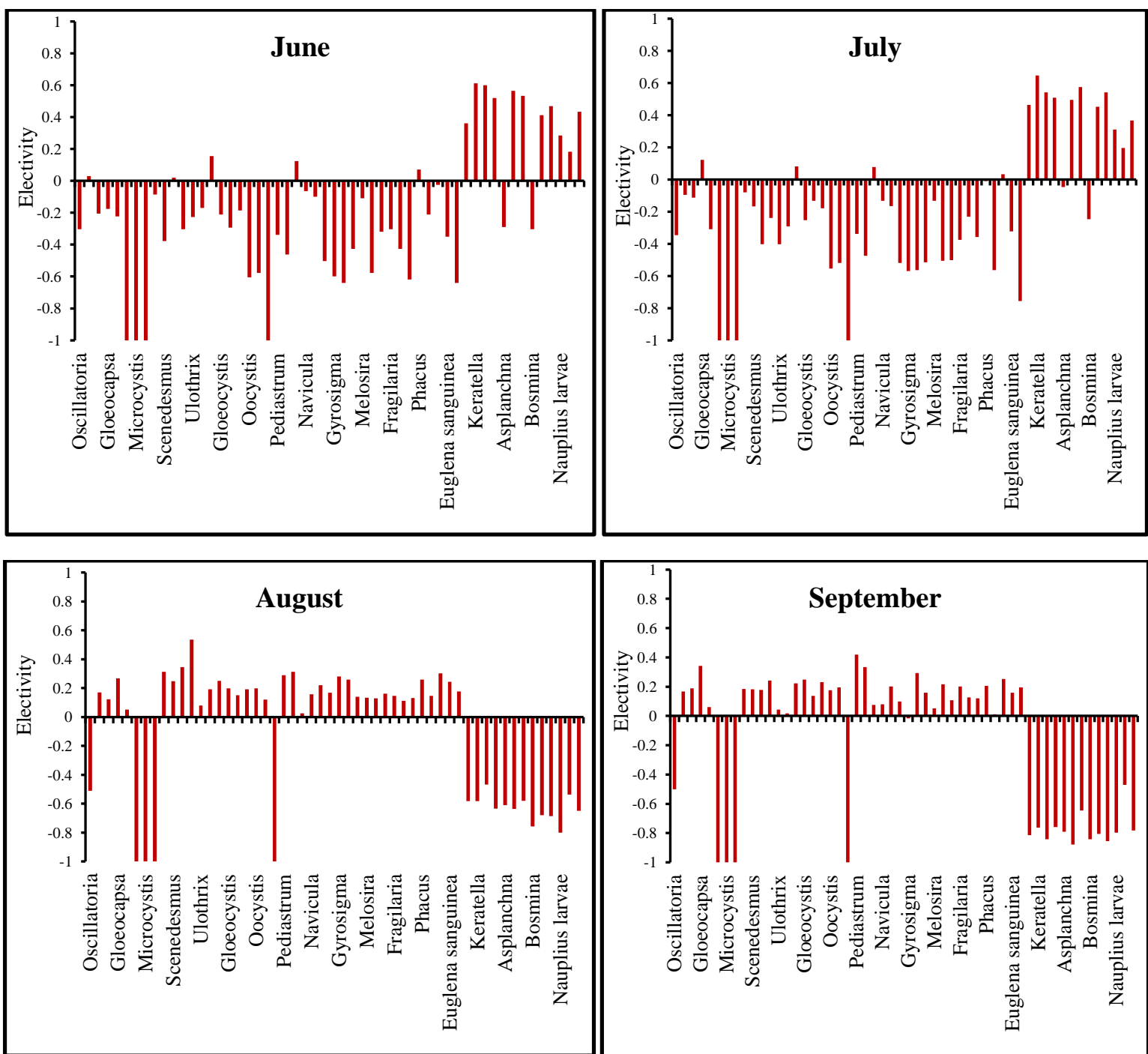

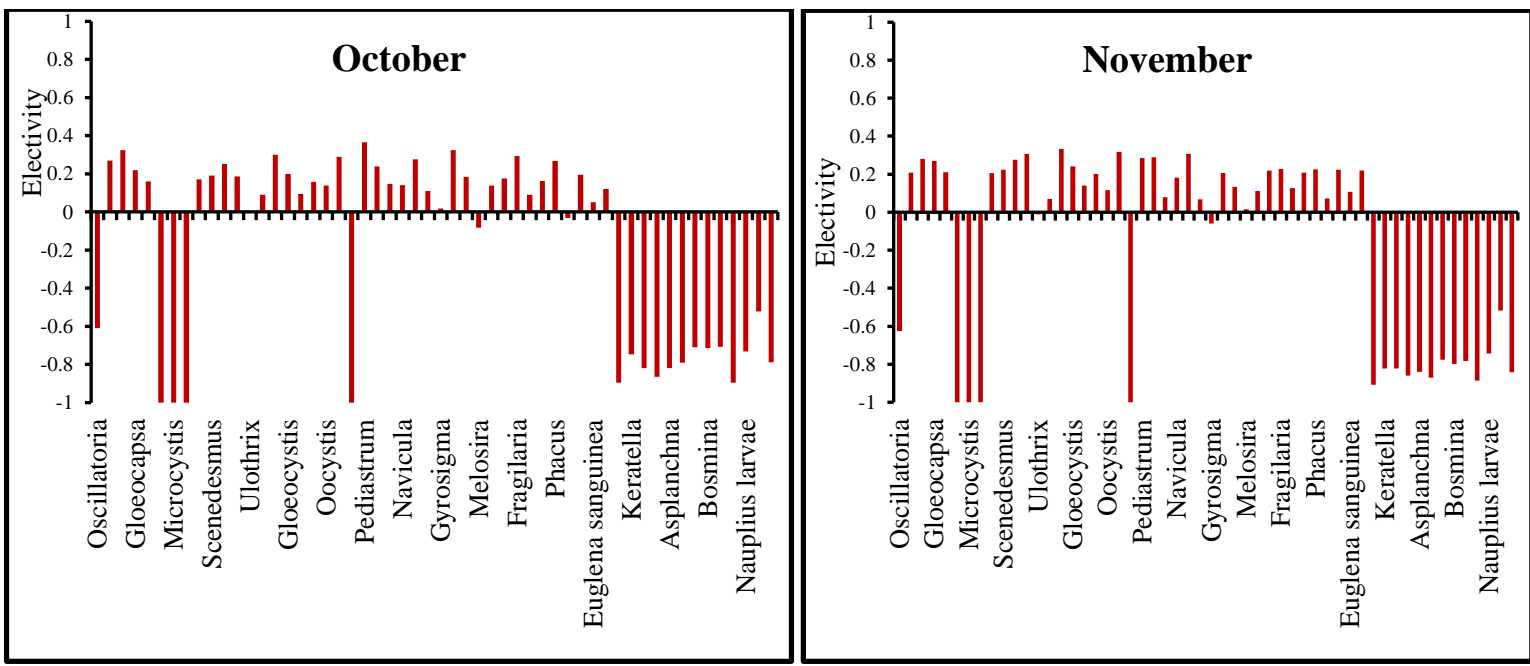

Fig-4: Ivlev's Electivity index throughout the season in Periphytic polyculture (PR-P) system considering plankton as food resource.

\section{DISCUSSION}

The present investigation found that during early stage of life (June-July) rohu prefers to consume zooplankton over phytoplankton in both the monoculture and polyculture environment. Earlier, Miah et al. (1984) [6] reported zooplankton as a preferable food of rohu fry over phytoplankton but later, Majumder et al. (2016) [17] stated the phytoplanktivorous nature of rohu. In AugustSeptember, the frequency of selectivity increased for algal food types, following a decrease in zooplanktonic organisms. Particularly, the fish exploited both the periphytic and planktonic algal food at the later phase. The decrease in abundance of zooplankton in the gut with gradual increase in abundance of periphytic and planktonic algal groups indicated shift in feeding habit by the fish towards the food of algal origin as the season progressed. A similar dietary shift for particular periphyton was observed on Oreochromis spp. [18]. Oedogonium, though abundant in the gut of rohu but it did not show a strong preference because of the high abundance in the pond environment. Arcella were found abundant in the gut irrespective of the season although it showed negative selection as the abundance of Arcella was much higher in the pond environment as compared to the gut of rohu. More particularly algal groups were taken predominantly during all the growth stages, however, the fish strongly rejected most of the large zooplankton and zooperiphyton during the later months.

By studying Ivlev's (1961) [16] electivity index, Khan and Siddique (1973) [11] found high and positive electivity for Chlorophyceae and Bacillariophyceae. But the present investigation found positive electivity indices for all the four major algal groups i.e. Chlorophyceae,
Bacillariophyceae, Cyanophyceae and Euglenophyceae during the later stage of life of the fish. Present finding concur with Rahman et al. (2006) [19] who studied growth, production and food preference of rohu in two culture environments i.e. monoculture and polyculture with common carp (C. carpio L.) using artificial and natural feeds in ponds. They observed rohu ingested twice as much as phytoplankton than zooplankton in environments with natural feed. The earlier reports with rohu as active periphyton feeder [20] did not consider gut analysis to confirm diet selectivity of rohu. Under substrate based environments, it was reported that growth of rohu is faster than substrate free environment. Azim et al. (2001a) [9] reported that its growth was $77 \%$ higher in substrate based pond than substrate free ponds. Azim et al. (2001b) [21] significantly observed that periphyton biomass decreases with increasing biomass of rohu in substrate based environment. In substrate based monoculture condition Majumder et al. (2016) [17] reported periphyton feeding nature of rohu. Contrary to Khan and Siddique (1973) [11], the present investigation found that rohu feed on phytoplankton throughout the life even in the early stage of life. But at early stage it prefers to consume zooplankton in higher quantity and phytoplankton in less quantity and even some blue green algae like Anabaena, Aphanocapsa and Chroococcus is preferred throughout the ontogeny of the fish. Greater inclination was observed for Arcella, and the small sized rotifers and large sized zooplankton or zoobenthos during the early stage but in very less quantity during the later stage of life. Sibbling et al. (1986) [22] reported that carps with lesser standard length retain larger zooplankton and detritus matter in the branchial sieve. However, this retention capacity decreases with growth of the fish [23]. Thus, morphological changes in the pond 
environment influenced the intake as well as availability of types of food items in the gut of the fish.

\section{CONCLUSION}

The study revealed planktivorous nature of feeding of rohu mostly on algal food organisms of periphytic and planktonic origin in both the culture environments. The present investigation suggests that rohu, irrespective of fingerling and adult stage, exerted a positive preference for phytoplankton. The study also supports the previous findings and suggests that rohu extends its feeding niche to periphyton along with plankton in substrate based system leading to accelerated biomass growth. Although rohu has been reported as exclusively plankton feeder, these observations suggest rohu as periphyton feeder in substrate based system. From the present study, electivity index also support such selection of periphyton by rohu when subjected to periphytic environment.

\section{REFERENCE}

[1] V.G. Jhingran, "Fish and Fisheries of India", 3rd edn, Hindustan Publishing Corporation, Delhi, India, 1991.

[2] F.A.O. "The State of World Fisheries and Aquaculture 2009", Food and Agriculture Organization of the United Nations, FAO, Rome, pp. 176, 2009.

[3] S.M. Das, S.K. Moitra, "Studies on the food of some common fishes of Uttar Pradesh, India. 1. Surface-feeders, mid-feeders and bottom feeders", Proceedings of the National Academy of Sciences (B), 25, 1-6, 1955.

[4] V.G. Jhingran, R.S.V. Pullin, "A hatchery manual for the common, Chinese and Indian major carp", 191p Asian Development Bank, ICLARM Studies and Reviews, 1985.

[5] M.A. Wahab, Z.F. Ahmed, M.S. Haq, M. Begum, "Compatibility of silver carp in the polyculture of cyprinid fishes", Progressive Agriculturist, 5, 221-227, 1994.

[6] M.I.U. Miah, S. Dewan, M. Wahiduzzaman, "Studies on the type and amount of food taken by silver carp Hypophthalmichthys molitrix (val.) and its diet patterns of feeding in Bangladesh pond", Bangladesh Journal of Fisheries, 7, 49-54, 1984.

[7] N.F.E.P. "Production enhancement of Indian major carps, Labeo rohita (Ham.) using bamboo trimmings as a substrate for the growth of periphyton", NFEP paper No. 10, Northwest Fisheries Extension Project, Parbatipur, Dinajpur, Bangladesh, 1997.

[8] M.R. Ramesh, K.M. Shankar, C.V. Mohan, T.J. Varghese, "Comparison of three plant substrates for enhancing carp growth through bacterial biofilm”, Aquaculture Engineering, 19, 119$131,1999$.

[9] M.E. Azim, M.A. Wahab, A.A. van Dam, M.C.M. Beveridge, M.C.J. Verdegem, "The potential of periphyton-based culture of two Indian major carps, Rohu Labeo rohita (Hamilton) and gonia Labeo gonius (Linnaeus)", Aquaculture Research, 32, 209216, 2001a.

[10] A. Muhammad, R. Iqbal, S.A. Rana, M. Athar, F. Iqbal, "Effect of feed cycling on specific growth rate, condition fector and RNA/DNA ratio of Labeo rohita", African Journal of Biotechnology, 5(17), 1551-1556, 2006.

[11] R.A. Khan, A.Q. Siddique, "Food selection by Labeo rohita and its feeding relationship with other major carps", Hydrobiologia, 43(3-4), 429-442, 1973.
[12] J.B. Lackey, "The manipulation and counting of river plankton and changes in some organisms due to formalin preservation", Public Health Report, 53, 2080p, 1938.

[13] A. Pentecost, "Introduction to Freshwater Algae", Edn 1 $1^{\text {st }}$, The Richmond Publishing Co. Ltd., Orchard Road, Richmond, Surrey, England, 1984.

[14] W.T. Edmondson, "Freshwater biology", International books and periodicals supply services, New Delhi, 1992.

[15] G.M. Perumal, A. Anand, "Manual of Freshwater Algae of Tamilnadu", Bishen Singh Mahendra Pal Singh, 23-A, New Connaught Place, Dehradun-248001, India, 2009.

[16] I.S. Ivlev, "Experimental ecology of the feeding of fishes", Yale University Press, 302p, New Heaven, Connecticut, USA, 1961.

[17] S. Majumder, P. Ghosh, S.K. Saha, S.K. Saikia, "Study on food selection of Labeo rohita (Hamilton, 1822) by determining electivity index in periphyton based and periphyton free monoculture pond", International Journal of Applied Research, 2(3), 4-7, 2016.

[18] A.K.Y. Haroon, K.A. Pittman, G. Blom, "Diet pattern and ration of two sizes of tilapia Oreochromis spp. in pond and paddy field", Asian Fisheries Science, 10, 281-301, 1998.

[19] M.M. Rahman, M.C.J. Verdegam, L.A.J. Nagelkerke, M.A. Wahab, A. Milstein, J.A.J. Verreth, "Growth, production and food preference of Labeo rohita (H.) in monoculture and in polycutlure with Common carp Cyprinus carpio (L.) under fed and non-fed ponds", Aquaculture, 257(1-4), 359-372, 2006.

[20] M.E. Azim, M.M. Rahman, M.A. Wahab, T. Asaeda, D.C. Little, M.C.J. Verdegem, "Periphyton-based pond polyculture system: a bioeconomic comparison of on-farm and on-station trials", Aquaculture, 242, 381-396, 2004.

[21] M.E. Azim, M.A. Wahab, A.A. van Dam, M.C.M. Beveridge, A. Milstein, M.C.J. Verdegem, "Optimization of fertilization rate for maximizing periohyton production on artificial substrates and their implications for periphyton-based aquaculture", Aquaculture Research, 32, 749-760, $2001 \mathrm{~b}$.

[22] F.A. Sibbling, J.W.M. Osse, A. Terlouw, "Food handling in the carp (Cyprinus carpio): its movement patterns, mechanisms and limitations", Journal of Zoology, 210, 161-203, 1986.

[23] F.A. Sibbling, "Specialization and limitations in the utilization of food resources by the carp, Cyprinus carpio: a study on oral food processing", Environmental Biology of Fishes, 22, 161-178, 1988. 